\title{
Pengaruh Motivasi Kerja, Disiplin Kerja, Dan Gaya Kepemimpinan Terhadap Kinerja Pegawai Di Lingkungan Rumah Sakit St. Carolus Summarecon Serpong
}

\author{
Pusporini Palupi J, S.S.T., M.M. \\ Dosen Falkutas Ekonomi, Universitas Pamulang \\ Email : dosen01399@unpam.ac.id
}

\begin{abstract}
ABSTRAK
Tujuan dari penelitian ini adalah untuk mengetahui seberapa besar pengaruh Pengaruh Motivasi Kerja, Disiplin Kerja, Dan Gaya Kepemimpinan terhadap Kinerja Pegawai baik parsial maupun simultan.

Desain penelitian yang digunakan dalam penyusunan penelitian ini adalah kuantitatif asosiatif kausal yang bertujuan untuk mengetahui pengaruh dari variabel bebas terhadap variabel terikat secara mendalam yang menggambarkan atau mengungkapkan masalah, situasi, peristiwa atau mengungkapkan fakta dan mencoba untuk menemukan solusi atau pemecahan masalah.

Hasil uji hipotesis berdasarkan pengujian parsial menunjukkan bahwa motivasi kerja berpengaruh positif dan signifikan terhadap kinerja sebesar 0,830. Disiplin kerja berpengaruh positif dan signifikan terhadap kinerja sebesar 0,872 dan Gaya kepemimpinan berpengaruh positif dan signifikan terhadap kinerja sebesar 0,831. Sedangkan Hasil analisis regresi berganda diperoleh nilai koefisien determinasi $\left(R^{2}\right)$ sebesar 0, 781 dan nilai $F_{\text {hitung }}$ lebih besar dari $F_{\text {tabel }}$ yaitu 156,726 > 2,67. Maka dapat disimpulkan bahwa variabel kinerja mampu dijelaskan oleh motivasi kerja, disiplin kerja dan gaya kepemimpinan sebesar $78,1 \%$ sisanya sebesar 21,9\% dijelaskan oleh variabel lain di luar penelitian ini.
\end{abstract}

Kata Kunci : Motivasi Kerja, Disiplin Kerja, Gaya Kepemimpinan, Kinerja 


\section{PENDAHULUAN}

\section{A. Latar Belakang}

Salah satu perusahaan yang bergerak di bidang jasa pelayanan kesehatan yang ada di Serpong yang dalam pencapaian visi dan misinya memerlukan kinerja karyawan yang prima dalam memberikan pelayanan kepada konsumen dan pelanggannya adalah rumah sakit ST. Carolus Summarecon Serpong. Rumah sakit ini merupakan salah satu perusahaan jasa yang secara langsung berhubungan dengan konsumen, maka sudah selayaknya karyawan memberikan pelayanan yang terbaik kepada konsumen maupun pelanggannya. Perasaan puas yang dirasakan konsumen atau pelanggan mencerminkan bahwa karyawan sudah menunjukkan kinerja yang baik dalam memberikan pelayanan.

Baik buruk hasil kerja

karyawan dapat dilihat dari standar kinerja yang telah ditetapkan perusahaan. Jika karyawan memberikan hasil kerja sesuai standar kinerja yang telah ditetapkan, maka kinerja karyawan tergolong baik. Peningkatan kinerja karyawan akan membawa kemajuan bagi perusahaan untuk dapat bertahan dalam suatu persaingan lingkungan bisnis yang tidak stabil. Oleh karena itu upayaupaya untuk meningkatkan kinerja karyawan merupakan tantangan manajemen yang paling serius karena keberhasilan untuk mencapai tujuan dan kelangsungan hidup perusahaan tergantung pada kualitas kinerja sumber daya manusia yang ada didalamnya.

Akan tetapi terdapat faktor negatif yang dapat menurunkan kinerja karyawan Rumah Sakit St. Carolus Summarecon Serpong, diantaranya adalah menurunnya keinginan karyawan untuk mencapai prestasi kerja. Penurunan kinerja tersebut dapat berdampak pada harapan yang diinginkan oleh instansi tidak dapat tercapai sepenuhnya.

$\begin{array}{lll} & \text { Karyawan } & \text { Rumah Sakit } \\ \text { St. } & \text { Carolus } & \text { Summarecon }\end{array}$

Serpong memiliki motivasi yang cukup tinggi untuk memperoleh kesejahteraan individu yang lebih namun tidak semua karyawan mengimbangi motivasi tersebut dengan kinerja yang maksimal. Karyawan memiliki kesadaran untuk menegakkan kedisiplinan kerja yang bisa dikatakan minim, sehingga antara keinginan dan kewajiban tidak seimbang. Hal ini dapat berpengaruh terhadap kinerja yang dihasilkan oleh karyawan, dengan kata lain kinerja yang diberikan oleh karyawan Rumah Sakit St. Carolus Summarecon Serpong tidak sesuai dengan harapan instansi. Dari permasalahan yang ditemukan kemudian timbul pemikiran bagaimana keseluruhan faktor tersebut saling berkesinambungan sehingga mempengaruhi kinerja karyawan.

\section{B. Perumusan Masalah}

Berdasarkan latar belakang dan identifikasi masalah yang telah 
diuraikan di atas, maka dapat dirumuskan masalah pada penelitian ini sebagai berikut :

1. Apakah terdapat pengaruh positif dan signifikan motivasi kerja terhadap kinerja pegawai Rumah Sakit St. CarolusSummaecon Serpong?

2. Apakah terdapat pengaruh positif dan signifikan disiplin kerja terhadap kinerja pegawai Rumah Sakit St. Carolus Summarecon Serpong?

3. Apakah terdapat pengaruh positif dan signifikan gaya kepemimpinan terhadap kinerja pegawai Rumah Sakit St. Carolus Summarecon Serpong?

4. Apakah terdapat pengaruh positif dan signifikan motivasi kerja, disiplin kerja, dan gaya kepemimpinan secara bersama - sama terhadap kinerja pegawai Rumah Sakit St. Carolus Summarecon Serpong?

\section{Tujuan Penelitian}

Adapun tujuan dari penelitian ini adalah untuk :

1. Mengetahui pengaruh motivasi kerja terhadap kinerja pegawaiRumah Sakit St. Carolus Summarecon Serpong.

2. Mengetahui pengaruh disiplin kerja terhadap kinerja pegawai Rumah Sakit St. Carolus Summarecon Serpong.
3. Mengetahui pengaruh gaya kepemimpinan terhadap kinerja pegawai Rumah Sakit St. Carolus Summarecon Serpong.

4. Mengetahui pengaruh motivasi kerja, disiplin kerja, dan gaya kepemimpinan secara bersama-sama terhadap kinerja pegawai Rumah Sakit St. Carolus Summarecon Serpong.

\section{Tinjauan Pustaka}

A. Motivasi Kerja

Peranan motivasi dalam bekerja sangat penting, para karyawan yang diperhatikan oleh pimpinan, diberikan fasilitas yang cukup oleh organisasi dan rekan kerja yang mendukung dapat melahirkan dorongan dalam dirinya untuk bekerja secara total guna mencapai tujuan organisasi.

Motivasi sering didefinisikan sebagai: "kesediaan untuk melaksanakan upaya tinggi untuk mencapai tujuan- tujuan keorganisasian, yang dikondisikan oleh kemampuan upaya, untuk memenuhi kebutuhan individual tertentu" Cascio dalam Husein Umar.

\section{B. Disiplin Kerja}

Menurut Nitisemito (2000:199) mengemukakan pengertian kedisiplinan yaitu sebagai suatu sikap, tingkah laku dan peraturan yang sesuai dengan peraturan perusahaan baik tertulis atau tidak tertulis. Kedisiplinan tidak terlepas dari tindakan manajemen untuk memberikan semangat pelaksanaan standar organisasi, ini adalah pelatihan yang mengarah pada upaya membenarkan dan melibatkan 
pengetahuan-pengetahuan sikap dan perilaku pegawai sehingga ada kemauan pada diri pegawai untuk menuju pada kerjasama dan prestasi yang lebih baik.

C. Kepemimpinan

Menurut Sunarto

(2005:33) menjelaskan kepemimpinan adalah proses memberi inspirasi kepada semua karyawan agar bekerja sebaikbaiknya untuk mencapai hasil yang diharapkan. Dengan kata lain, kepemimpinan adalah pengaruh antar peribadi yang dijalankan dalam situasi tertentu, serta melalui proses komunikasi kearah tercapainya tujuan. Kepemimpinan menyangkut proses pengaruh sosial yang disengaja dijalankan oleh seorang terhadap orang lain.

Sejalan dengan penjelasan di atas, Mangkuprawira dan Hubeis (2007:137) menerangkan kepemimpinan adalah gaya dan perilaku seseorang untuk membuat orang lain mengikuti apa yang dikehendakinya.

Definisi lain menyatakan bahwa kepemimpinan melibatkan pengikut dan memberikan nilai-nilai pengikut dengan cara meningkatkan keterampilan dan kepercayaan diri. Kepemimpinan menunjukkan adanya perhatian pribadi yang menghubungkan kepentingan individu dan kolektif, yang mengakibatkan komitmen visi organisasi menjadi baik.

\section{Kinerja}

Kinerja

menurut

Mangkunegara (2000:67) Kinerja (prestasi kerja) adalah hasil kerja secara kualitas dan kuantitas yang dicapai oleh seseorang/pegawai dalam melaksanakan tugasnya sesuai dengan tanggung jawab yang diberikan kepadanya. Kinerja merupakan suatu konsep yang bersifat universal yang merupakan efektifitas operasional suatu organisasi, bagian organisasi dan karyawannya berdasarkan standar dan kriteria yang telah ditetapkan sebelumnya.Organisasi pada dasarnya dijalankan oleh manusia maka kinerja sesungguhnya merupakan perilaku manusia dalam memainkan peran yang mereka lakukan di dalam suatu organisasi untuk memenuhi standar perilaku yang telah ditetapkan agar membuahkan hasil dan tindakan yang diinginkan.

\section{METODE PENELITIAN}

\section{A. Lokasi dan Waktu Penelitian}

Penelitian ini dilakukan di Rumah Sakit St. Carolus yang berlokasi di Jl. Boulevard Kav. 08 Gading Serpong - Tangerang. Proses penelitian ini akan dilaksanakan dalam waktu selama 4 bulan dari bulan April - juli 2015. Penelitian ini secara bertahap di awali dengan prasurvey, pembuatan instrumen, pengolahan data.

\section{B. Metode Penelitian}

Adapun pendekatan metode penelitian yang digunakan adalah kuantitatif dengan eksplanasi deskriptif. Artinya dalam melakukan pembahasan, penelitian ini berdasarkan pendekatan angka yang kemudian dinarasikan secara faktual sebagaimana adanya data tersebut (Freddy Rangkuti, 2011:17). Lebih lanjut metode penelitian yang digunakan adalah asosiatif kausal. Asosiatif kausal merupakan suatu penelitian yang mengkaji dan 
menganalisa hubungan-hubungan antara satu variabel dengan variabel lainnya atau bagaimana suatu variabel mempengaruhi variabel lainnya (Husein Umar, 2008:93). Merujuk pada judul, terlihat jelas bahwa penelitian ini ingin mencari tahu seberapa besar pengaruh variabel eksogen terhadap variabel endogen. Dengan kata lain, adanya perubahan variabel bebas dapat berdampak pada naik atau turunnya variabel terikat, penelitian jenis ini biasanya bersifat asimetris.

\section{Populasi dan Sampel}

Populasi dalam penelitian ini adalah seluruh karyawan yang ada di RS. Sint Carolus Summarecon Serpong. Berikut rincian jumlah populasi pegawai RS. Sint Carolus Summarecon Serpong. Teknik sampling yang digunakan pada penelitian adalah salah satu dari metode teknik sampel sensus atau sampling jenuh, yakni keseluruhan populasi digunakan sebagai sampel dalam penelitian, dikarenakan keterbatasan populasi yang ada atau penelitian ingin membuat hasil generalisasi dengan kesalahan yang kecil (Sugiyono, 2008:122). Dengan demikian sampel dalam penelitian ini berjumlah 136 responden.

\section{E. Teknik Pengumpulan Data}

Pengumpulan data dari responden yang digunakan adalah dengan metode komunikasi dengan menggunakan kuesioner dengan pertanyaan tertutup. Pertanyaan tertutup adalah pertanyaan yang sudah mengarah pada jawaban yang alternatifnya sudah ditentukan, dibuat dengan skala Likert. metode yang digunakan adalah data primer. Mengingat data yang dibutuhkan berupa pendapat, tanggapan, persepsi, sikap dan prilaku, maka penulis secara langsung menemui responden yang menjadi subjek penelitian dengan cara menyebarkan kuesioner.

\section{F. Definisi Variabel}

1. Variabel Motivasi kerja

Motivasi merupakan suatu dorongan dari eksternal maupun internal, baik finansial maupun nonfinansial guna melahirkan semangat kerja karyawan dalam mencapai tujuan organisasi.

2. Variabel Disiplin Kerja

Sikap dan prilaku sadar karyawan dalam menaati aturan, kebijakan dan etika guna mencapai tujuan organisasi.

3. Variabel Gaya Kepemimpinan

Perilaku atau cara yang dipilih dan dipergunakan pemimpin dalam mempengaruhi pikiran, perasaan, sikap dan perilaku para anggota organisasi bawahannya.

4. Varibel Kinerja Pegawai

Hasil kerja secara kualitas dan kuantitas yang dicapai oleh pegawai dalam melaksanakan tugasnya sesuai dengan tanggung jawab yang diberikan kepadanya.

\section{HASIL DAN PEMBAHASAN}

\section{A. Hasil Penelitian}

1. Uji Validitas

Pengujian validitas data variable penelitian menggunakan menyatakan bahwa jika koefisien korelasi positif dan > 0,3 maka indikator bersangkutan dianggap valid. Perhitungan koefisien korelasi dilakukan dengan software SPSS. 
a) Tabel 3.1 Hasil Uji Variabel Motivasi Kerja $\left(\mathrm{X}_{1}\right)$

\begin{tabular}{|l|l|l|l|l|}
\hline No & Kuesioner & Batas Kritis & r - Value & Hasil Uji \\
\hline 1 & Pernyataan butir 1 & 0,3 & 0,771 & Valid \\
\hline 2 & Pernyataan butir 2 & 0,3 & 0,820 & Valid \\
\hline 3 & Pertanyaan butir 3 & 0,3 & 0,878 & Valid \\
\hline 4 & Pernyataan butir 4 & 0,3 & 0,922 & Valid \\
\hline 5 & Pertanyaan butir 5 & 0,3 & 0,882 & Valid \\
\hline 6 & Pertanyaan butir 6 & 0,3 & 0,893 & Valid \\
\hline 7 & Pernyataan butir 7 & 0,3 & 0,924 & Valid \\
\hline 8 & Pertanyaan butir 8 & 0,3 & 0,881 & Valid \\
\hline 9 & Pertanyaan butir 9 & 0,3 & 0,879 & Valid \\
\hline 10 & Pertanyaan butir 10 & 0,3 & 0,847 & Valid \\
\hline 11 & Pertanyaan butir 11 & 0,3 & 0,901 & Valid \\
\hline 12 & Pertanyaan butir 12 & 0,3 & 0,836 & Valid \\
\hline
\end{tabular}

\section{Sumber : Data Primer Diolah}

b) Tabel 3.2 Hasil Uji Validitas Disiplin kerja $\left(\mathrm{X}_{2}\right)$

\begin{tabular}{|l|l|l|l|l|}
\hline No & Kuesioner & Batas Kritis & $\mathbf{r}-$ Value & Hasil Uji \\
\hline 1 & Pernyataan butir 1 & 0,3 & 0,839 & Valid \\
\hline 2 & Pernyataan butir 2 & 0,3 & 0,832 & Valid \\
\hline 3 & Pertanyaan butir 3 & 0,3 & 0,775 & Valid \\
\hline 4 & Pernyataan butir 4 & 0,3 & 0,344 & Valid \\
\hline 5 & Pertanyaan butir 5 & 0,3 & 0,846 & Valid \\
\hline 6 & Pertanyaan butir 6 & 0,3 & 0,862 & Valid \\
\hline 7 & Pernyataan butir 7 & 0,3 & 0,786 & Valid \\
\hline 8 & Pertanyaan butir 8 & 0,3 & 0,801 & Valid \\
\hline 9 & Pertanyaan butir 9 & 0,3 & 0,864 & Valid \\
\hline 10 & Pertanyaan butir 10 & 0,3 & 0,807 & Valid \\
\hline 11 & Pertanyaan butir 11 & 0,3 & 0,859 & Valid \\
\hline 12 & Pertanyaan butir 12 & 0,3 & 0,787 & Valid \\
\hline
\end{tabular}

\section{Sumber : Data Primer Diolah}

c) Tabel 3.3 Hasil Uji Validitas Variabel Gaya Kepemimpinan $\left(\mathrm{X}_{3}\right)$

\begin{tabular}{|l|l|l|l|l|}
\hline No & Kuesioner & Batas Kritis & r - Value & Hasil Uji \\
\hline 1 & Pernyataan butir 1 & 0,3 & 0,841 & Valid \\
\hline 2 & Pernyataan butir 2 & 0,3 & 0,893 & Valid \\
\hline 3 & Pertanyaan butir 3 & 0,3 & 0,935 & Valid \\
\hline 4 & Pernyataan butir 4 & 0,3 & 0,925 & Valid \\
\hline 5 & Pertanyaan butir 5 & 0,3 & 0,885 & Valid \\
\hline 6 & Pertanyaan butir 6 & 0,3 & 0,895 & Valid \\
\hline 7 & Pernyataan butir 7 & 0,3 & 0,865 & Valid \\
\hline 8 & Pertanyaan butir 8 & 0,3 & 0,858 & Valid \\
\hline
\end{tabular}




\begin{tabular}{|l|l|l|l|l|}
\hline 9 & Pertanyaan butir 9 & 0,3 & 0,858 & Valid \\
\hline 10 & Pertanyaan butir 10 & 0,3 & 0,892 & Valid \\
\hline 11 & Pertanyaan butir 11 & 0,3 & 0,877 & Valid \\
\hline 12 & Pertanyaan butir 12 & 0,3 & 0,291 & Valid \\
\hline
\end{tabular}

Sumber : Data Primer Diolah

d. Tabel 3.4 Hasil Uji Validitas Variabel Variabel Kinerja (Y)

\begin{tabular}{|l|l|l|l|l|}
\hline No & Kuesioner & Batas Kritis & $\mathbf{r}-$ Value & Hasil Uji \\
\hline 1 & Pernyataan butir 1 & 0,3 & 0,880 & Valid \\
\hline 2 & Pernyataan butir 2 & 0,3 & 0,828 & Valid \\
\hline 3 & Pertanyaan butir 3 & 0,3 & 0,905 & Valid \\
\hline 4 & Pernyataan butir 4 & 0,3 & 0,908 & Valid \\
\hline 5 & Pertanyaan butir 5 & 0,3 & 0,930 & Valid \\
\hline 6 & Pertanyaan butir 6 & 0,3 & 0,892 & Valid \\
\hline 7 & Pernyataan butir 7 & 0,3 & 0,894 & Valid \\
\hline 8 & Pertanyaan butir 8 & 0,3 & 0,879 & Valid \\
\hline 9 & Pertanyaan butir 9 & 0,3 & 0,897 & Valid \\
\hline 10 & Pertanyaan butir 10 & 0,3 & 0,883 & Valid \\
\hline 11 & Pertanyaan butir 11 & 0,3 & 0,799 & Valid \\
\hline 12 & Pertanyaan butir 12 & 0,3 & 0,841 & Valid \\
\hline
\end{tabular}

\section{Sumber : Data Primer Diolah}

2. Uji Reliabilitas

Uji reliabilitas dilakukan untuk menguji apakah jawaban dari responden konsisten atau stabil, suatu variabel penelitian dikatakan reliabel apabila memenuhi kriteria sebagai berikut :

1) Jika Chronbach alpha > $>, 6$ dikatakan reliable

2) Jika Chronbach alpha < 0,6 dikatakan tidak reliable

Tabel 3. 5 Hasil Uji Reliabilitas

\begin{tabular}{|l|l|l|l|}
\hline Variabel & $\begin{array}{l}\text { Batas } \\
\text { Reabilitas }\end{array}$ & $\begin{array}{l}\text { Alpha } \\
\text { Chronbach's }\end{array}$ & Keterangan \\
\hline Motivasi kerja $\left(\mathrm{X}_{1}\right)$ & 0,6 & 0,976 & Reliabel \\
\hline Disiplin Kerja $\left(\mathrm{X}_{2}\right)$ & 0,6 & 0,965 & Reliabel \\
\hline Gaya Kepemimpinan $\left(\mathrm{X}_{3}\right)$ & 0,6 & 0,978 & Reliabel \\
\hline Kinerja (Y) & 0,6 & 0,973 & Reliabel \\
\hline
\end{tabular}

\section{Sumber : Data Primer Diolah}

B. Uji Asumsi Klasik

1. Uji Normalitas

Hasil pengujian normalitas data pada variabel motivasi kerja, disiplin kerja dan gaya kepemimpinan terhadap kinerja di peroleh hasil sebagai berikut : 
Histogram

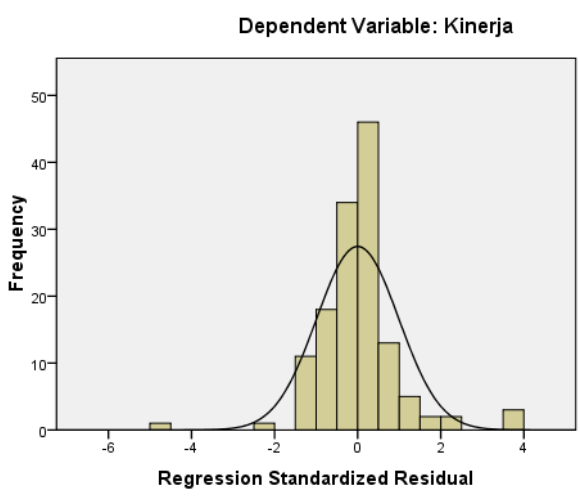

Berdasarkan data histogram di atas dapat dilihat bahwa kurva tersebut memiliki nilai histogram yang berdistribusi normal. Hal ini dapat dilihat dari sebaran data yang menyebar di dalam garis skewness (kemencengan kanan kiri). Karena uji normalitas bukan dilakukan pada masing-masing variabel tetapi pada nilai residualnya. Analisis lebih lanjut dengan menggunakan Normal Probabilty Plot of Regression Standardized residual dapat dilihat pada gambar di bawah ini:
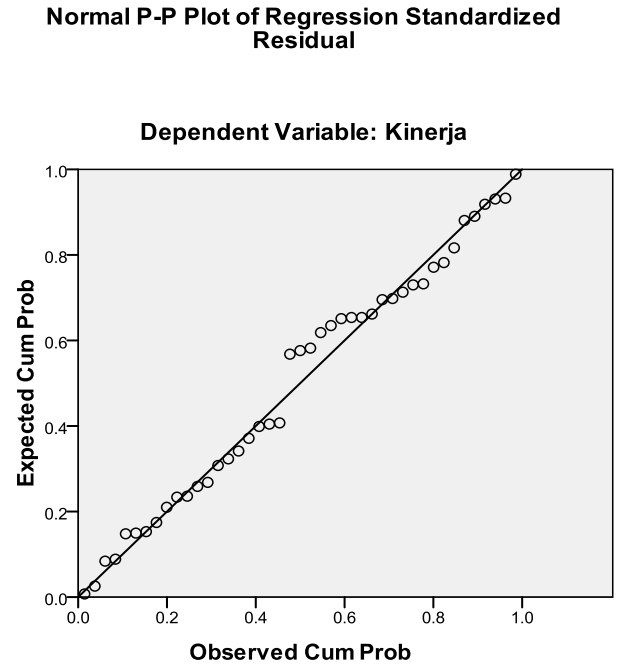

Dari gambar di atas dapat di simpulkan bahwa nilai residual terdistribusi secara normal, di mana pada gambar tersebut titik-titik nilai residual yang ada pada tabel alurnya mengikuti garis diagonal yang menunjukkan tingkat normalitas nilai-nilai residual yang ada. Oleh karena terpenuhinya asumsi normalitas maka penelitian ini dapat dilanjutkan pada analisa statistik berikutnya.

\section{Uji Heteroskedastisitas}

Model regresi yang baik adalah regresi yang tidak terdapat heteroskedatisitas, yaitu model regresi yang memiliki persamaan variance residual suatu periode pengamatan dengan periode pengamatan yang lain. Uji heteroskedastisitas ini dapat dilihat pada gambar di bawah ini,

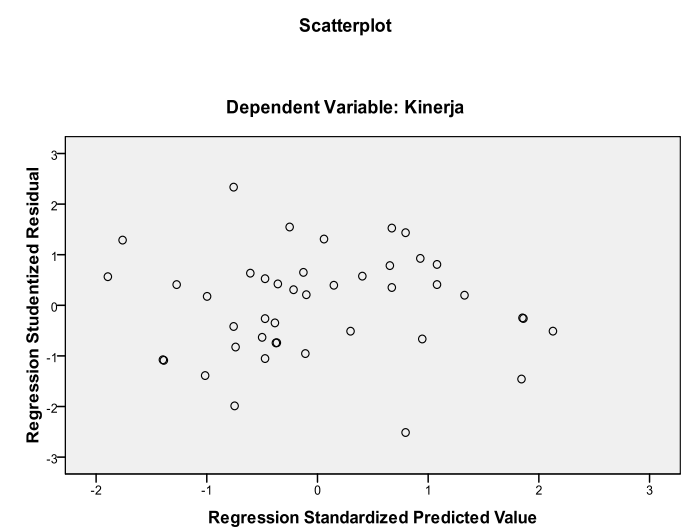

Berdasarkan gambar hasil pengolahan SPSS (Scatterplot) di atas maka dapat dilihat titik residual menyebar secara acak merata, tidak terjadi adanya pengelompokan data yang signifikan, sehingga data ini telah memenuhi syarat hesteroskedastisitas, yang artinya data dapat dilanjutkan dalam pengujian regresi.

3. Uji multikolinearitis

Berdasarkan data hasil Pengujian menggunakan Nilai Tolerance dan VIF menunjukkan 
bahwa nilai nilai tolerancenya lebih kecil sebesar dari 1,00 dan nilai VIF lebih kecil dari 10. Hal ini dapat di artikan bahwa tidak terdapat Multikolinearitas pada penelitian ini.

Tabel 3. 6 Hasil Uji Multikolinearitas

\begin{tabular}{|ll|l|l|l|l|l|}
\hline \multirow{2}{*}{ Model } & \multicolumn{2}{|l|}{ Correlations } & \multicolumn{2}{l|}{ Collinearity Statistics } \\
\cline { 2 - 7 } & Zero-order & Partial & Part & Tolerance & VIF \\
\hline $1 \quad$ (Constant) & & & & & \\
& Motivasi kerja & .813 & .204 & .097 & .166 & 6.025 \\
Disiplin Kerja & .831 & .022 & .010 & .106 & 9.397 \\
Gaya & .873 & .497 & .268 & .175 & 5.703 \\
Kepemimpinan & & & & & \\
\hline
\end{tabular}

\section{Sumber hasil olahan SPSS 17}

\section{Uji Autokorelasi} Berdasarkan perhitungan diketahui bahwa nilai DW lebih besar dari Du atau DW tabel yakni sebesar 2,010>1,765. Artinya bahwa model ini terbebas

Tabel 3.7 Hasil Uji Autokorelasi

\begin{tabular}{|c|c|c|c|c|c|c|}
\hline \multirow[b]{2}{*}{ Model } & \multicolumn{5}{|l|}{ Change Statistics } & \multirow[b]{2}{*}{ Durbin-Watson } \\
\hline & R Square Change & F Change & df1 & $\mathrm{df} 2$ & Sig. F Change & \\
\hline 1 & .781 & 156.726 & 3 & 132 & .000 & 2.010 \\
\hline
\end{tabular}

\section{Sumber hasil olahan SPSS 17}

5. Uji Koefisien Determinasi

1. Uji Koefisien Determinasi Pada uji simultan diketahui variabel motivasi kerja, disiplin kerja dan gaya kepemimpinan secara bersama-sama berpengaruh positif dan signifikan terhadap kinerja, namun belum diketahui besaran nilai kontribusi ketiga dari asumsi otokorelasi, di mana tidak ada hubungan antar variabel bebas sehingga model ini dapat dilanjutkan dalam analisis regresi linear berganda. 
Tabel 3.8 : Koefisien Determinasi

Model Summary ${ }^{b}$

\begin{tabular}{|l|l|l|l|l|}
\hline Model & $\mathrm{R}$ & R Square & Adjusted R Square & $\begin{array}{l}\text { Std. Error of the } \\
\text { Estimate }\end{array}$ \\
\hline 1 & $.884^{\mathrm{a}}$ & .781 & .776 & 2.953 \\
\hline
\end{tabular}

a. Predictors: (Constant), Gaya Kepemimpinan, Motivasi kerja, Disiplin Kerja

b. Dependent Variable: Kinerja

\section{Uji Signifikasi}

1. Uji Simultan ( Uji F )

a. Jika F-hitung < F-tabel berarti H0 diterima dan Ha ditolak

b. Jika F-hitung > F-tabel berarti H0 ditolak dan Ha diterima

Ketentuan F-tabel diperoleh dengan cara membandingkan jumlah variabel independen dengan taraf signifikan (3 variabel : 0.05), maka diperoleh F-tabel sebesar 2,67.

menunjukkan secara statistik bahwa motivasi kerja $\left(\mathrm{X}_{1}\right)$, disiplin kerja $\left(\mathrm{X}_{2}\right)$ dan gaya kepemimpinan $\quad\left(\mathrm{X}_{3}\right)$ secara bersama-sama terbukti berpengaruh positif dan signifikan terhadap kinerja dengan nilai $\mathrm{F}_{\text {hitung }}$ lebih besar dari $\mathrm{F}_{\text {tabel }}$ yaitu $156,726>2,67$.

Adapun hasil pengolahan data terhadap pengujian statistic $\mathrm{F}$, dapat dilihat pada tabel-tabel dibawah ini: Tabel 3.9. Uji Simultan (F)

ANOVA $^{b}$

\begin{tabular}{|l|l|l|l|l|l|}
\hline Model & Sum of Squares & df & Mean Square & F & Sig. \\
\hline 1 Regression & 4099.952 & 3 & 1366.651 & 156.726 & $.000^{\mathrm{a}}$ \\
Residual & 1151.040 & 132 & 8.720 & & \\
Total & 5250.993 & 135 & & & \\
\hline
\end{tabular}

a. Predictors: (Constant), Gaya Kepemimpinan, Motivasi kerja, Disiplin Kerja

b. Dependent Variable: Kinerja

\section{Sumber: Data Primer Diolah SPSS}

\section{B. Pembahasan Penelitian}

1. Pengaruh motivasi kerja terhadap kinerja

Uji deskriptif hasil kuesioner diperoleh informasi bahwa dimensi variabel motivasi kerja yang memiliki nilai terendah adalah kebutuhan akan prestasi yaitu sebanyak 73 responden menyatakan sangat setuju atau $54 \%$ dari populasi. Hasil ini memberikan penjelasan, pada faktanya pegawai Rumah Sakit St. Carolus mengakui belum optimalnya motivasi kerja. Hal ini nampak jelas pada prilaku kerja 
yang bersifat monoton, yakni para pegawai kaku dan datar dalam menjalankan pekerjaan, di mana tidak ada perlakuan lebih untuk dapat menunjukkan hasil kerja yang maksimal.

Lebih lanjut berdasarkan hasil uji hipotesis di atas, diperoleh angka $t_{\text {hitung }}$ penelitian sebesar $16,157>$ ttabel sebesar 1,977 dan memiliki nilai signifikan lebih rendah dari batas minimum yang disyaratkan 0,000 $<0,05$ sehingga $\mathrm{H} 0$ ditolak dan $\mathrm{Ha} 4$ diterima. Artinya ada pengaruh signifikan variabel motivasi terhadap prestasi dengan nilai pengaruh sebesar 0,344 .

2. Pengaruh disiplin kerja terhadap kinerja

Hasil sebaran kuesioner diperoleh data bahwa disiplin kerja pegawai belum optimal. Hal ini dapat dilihat dari tanggapan responden, hanya 72 (53\%) responden sajalah yang menyatakan sangat setuju. Ini mengisyaratkan bahwa kesadaran karyawan untuk mematuhi kedisiplinan yang diterapkan rumah sakit belum sepenuhnya dipatuhi.

3. Pengaruh gaya kepemimpinan terhadap kinerja

Berdasarkan uji deskripsi hasil kuesioner membuktikan bahwa gaya kepemimpinan otoriter memiliki presentasi sebesar $49 \%$ atau sebanyak 67 responden menyatakan sangat setuju. Hasil ini menjelaskan fakta lapangan bahwa masih terhadap kepala bagian rumah sakit yang menggunakan kepemimpinan structural. hasil uji regresi linear terbukti variabel gaya kepemimpinan berpengaruh positif dan signifikan terhadap kinerja sebesar 0,291.

4. Pengaruh motivasi kerja, disiplin kerja dan gaya kepemimpinan terhadap kinerja.

hasil uji simultan membuktikan bahwa motivasi kerja, disiplin kerja dan gaya kepemimpinan bersama-sama berpengaruh positif dan signifikan terhadap kinerja dengan nilai koefisien determinasi sebesar $78,1 \%$. Hasil ini membuktikan bahwa dalam menjalankan tugas tidak terlepas dari motivasi. Motivasi menjadi energi seseorang dalam bekerja, dengan motivasi seseorang merasa senang, penuh semangat, komitmen dan totalitas dalam bekerja sehingga ia akan melakukan yang terbaik guna mencapai tujuan organisasi.

\section{KESIMPULAN DAN SARAN}

\section{A. Kesimpulan}

Berdasarkan hasil analisis dan pembahasan pada bab sebelumnya, maka dapat diambil kesimpulan sebagai berikut :

1. Motivasi kerja terbukti berpengaruh positif dan signifikan terhadap kinerja pegawai RumahSakit St. Carolus Summarecon Serpong sebesar 0,344.

2. Disiplin kerja terbukti berpengaruh positif dan signifikan terhadap kinerja 
pegawai RumahSakit St. Carolus Summarecon Serpong sebesar 0,146.

3. Gaya kepemimpinan terbukti berpengaruh positif dan signifikan terhadap kinerja Pegawai RumahSakit St. Carolus Summarecon Serpong sebesar 0,291.

4. Motivasi kerja, disiplin kerja, dan gaya kepemimpinan terbukti secara simultan berpengaruh positif dan signifikan terhadap kinerja pegawai Rumah Sakit St. Carolus Summarecon Serpong sebesar 78,1 \% sisanya sebesar $21,9 \%$ dijelaskan oleh variabel lain diluar penelitian ini.

\section{B. Saran}

Berdasarkan hasil analisis dan kesimpulan penelitian,maka ada beberapa saran sebagai berikut :

1. Berdasarkan deskripsi hasil kuesioner dimensi terendah dari variabel motivasi adalah kebutuhan akan prestasi. Kiranya pihak manajemen mau menggali dan penelusuran mengenai apaapa saja yang dapat membangkitkan prestasi kerja karyawan.

2. Hasil uji kuesioner diketahui dimensi disiplin kerja yang paling rendah adalah keadilan. Kiranya pihak manajemen untuk lebih terbuka dan terus melakukan evaluasi terhadap kebijakankebijakan yang diterapkan oleh masing-masing kepala bagian.
3. Hasil sebaran kuesioner diperoleh informasi mengenai dimensi gaya kepemimpinan masih terdapat gaya kepemimpinan otoriter. Kiranya jajaran manajemen rumah sakit melakukan pengawasan dan evaluasi berkala kepada setiap pimpinan departemen kesehatan.

4. Berdasarkan analisis regresi linear diketahui variabel motivasi kerja adalah variabel yang berpengaruh kecil. Ini memberikan saran, kiranya pihak manajemen memperhatikan apa yang menjadi semangat kerja para pegawai.

\section{DAFTAR PUSTAKA}

Anggraeni, Fitria., 2011, pengaruh motivasi, kompensasi, lingkungan kerja, pelatihan dan pengembangan. $s d m$ terhadap kinerja pegawai, jurnal Falkutas Ekonomi UIN Jakarta.

Ardana, dkk., 2011, Manajemen sumber Daya Manusia, Graha Ilmu, Jakarta.

Ardana, Mujiati dan Utama., 2012, Manajemen Sumber Daya Manusia, Graha Ilmu, Yogyakarta.

As'ad, M., 2009, Psikologi Industri: Seri Sumber Daya Manusia, Liberty, Yogjakarta.

Bambang Wahyudi, 2002, Manajemen Sumber Daya Manusia, Sulita, Bandung.

Brahmasari, Ida Ayu. Agus Suprayetno, 2008,Pengaruh 
Motivasi Kerja,

Kepemimpinan dan Budaya Organisasi Terhadap

Kepuasan Kerja Karyawan serta Dampaknya pada Kinerja Perusahaan (Studi kasus pada PT. Pei Hai International Wiratama Indonesia). Jurnal Manajemen dan Kewirausahaan, Vol.10, No.2, Surabaya.

Danang, Sunyoto, 2012, Manajemen Sumber Daya Manusia, PT. Buku Seru, Jakarta.

Dessler, Gary., 1997, Human Resource Management, pearson prentice Hall.

Ferdinand, Augusty, 2000, Metode Penelitian Edisi,Badan Universitas Semarang.
Freddy Rangkuti, 2007, Manajemen Persediaan,

PT. RajaGrafindo Persada, Jakarta.

Ghozali, Imam., 2005, Aplikasi Analisis Multivariate dengan program SPSS, Badan penerbit Universitas Diponegoro, Semarang.

Grimsey, D. \& Lewis, M. K., 2004, Public Private Partnerships: The Worldwide Revolution in Infrastructure Provision and Project Finance, Edward Elgar, Inc., UK.

Hadi, Sutrisno. 2003,Manajemen Persionalia, Andi Offset, Yogyakarta.

Handoko TH., 2003, Manajemen personalia dan Sumber Daya Manusia, BPFE, Yogyakarta. 